\title{
Seasonal dynamics of Rhipicephalus sanguineus (Acari: Ixodidae) in dogs from a police unit in Goiânia, Goiás, Brazil
}

\author{
Dinâmica sazonal de Rhipicephalus sanguineus (Acari: Ixodidae) em cães de uma unidade da polícia de \\ Goiânia, Goiás, Brasil
}

\author{
Carla Cristina Braz Louly ${ }^{I}$ Iracele Nogueira Fonseca ${ }^{\mathrm{I}}$ Vilma Ferreira de Oliveira ${ }^{\mathrm{I}}$ \\ Guido Fontgalland Coelho Linhares ${ }^{\mathrm{I}}$ Liliana Borges de Menezes $^{\mathrm{I}}$ \\ Lígia Miranda Ferreira Borges ${ }^{\mathrm{II}}$
}

\section{ABSTRACT}

The seasonal dynamics of Rhipicephalus sanguineus ticks was evaluated in dogs at a Police Unit in Goiânia, Goiás, Brazil, from July 2001 to July 2002. The study was carried out on seven naturally infested dogs (two English Cocker Spaniels and five mongrel dogs), with ages between six months and 10 years. Every two weeks, the numbers of feeding larvae, nymphs, and adults were determined. Dogs showing infestation levels above 500 adult ticks received three acaricide treatments. Considering that the treatments had affected the development of some peaking populations of ticks, it was inferred the occurrence of the following peaks: - larvae (four peaks): from August to November, from November to February, from March to May, and from May to July; - nymphs (five peaks): from July to September, from October to December, from December to February, from March to May, and from June to July; - adults (four peaks): from July to October, from October to January, from January to March, and from April to July. The occurrence of these consecutive peaks of activity of each stage of $\boldsymbol{R}$. sanguineus may indicate that this tick can develop up to four generations per year in Goiânia. On the other hand, if the acaricide treatment did not interfere with the development of $\boldsymbol{R}$. sanguineus peaks, more than four peaks of each stage have occurred on the dogs. In this case, it is acceptable to infer that more than one population of $\boldsymbol{R}$. sanguineus was developing within the kennel concomitantly. The mean numbers of each tick stage was similar in the different seasons. The main attachment sites were located on the neck, chest, forelegs, armpits, ears, between toes and on the head. The number of adult ticks feeding on English Cocker Spaniel dogs was 1.4 to 11.5 times higher than that feeding on mongrel dogs.

Key words: Rhipicephalus sanguineus, Brown dog tick, mongrel dogs, English Cocker Spaniel dogs, seasonal dynamics.

\section{RESUMO}

O estudo de dinâmica sazonal de Rhipicephalus sanguineus foi desenvolvido em cães de uma unidade da polícia de Goiânia, Goiás, Brasil, de julho de 2001 a julho de 2002. Sete cães naturalmente infestados com $\boldsymbol{R}$. sanguineus (dois da raça Cocker Spaniel Inglês, e cinco cães sem raça definida), com idades variando de 6 meses a 10 anos, foram utilizados no monitoramento da infestação. A cada duas semanas, o número de larvas, ninfas e adultos parasitando os animais era contado. Três tratamentos acaricidas foram feitos nos cães que tiveram níveis de infestação de 500 adultos. Considerando que os tratamentos interferiram no desenvolvimento de alguns picos do carrapato, pôde-se inferir que ocorreram nos quatro picos de larvas: de agosto a novembro, de novembro a fevereiro, de março a maio e de maio a julho; cinco picos de ninfas: de julho a setembro, de outubro a dezembro, de dezembro a fevereiro, de março a maio e de junho a julho, e quatro picos de adultos: de julho a outubro, de outubro a janeiro, de janeiro a março e de abril a julho. A ocorrência destes picos consecutivos de cada estágio pode indicar que o $\boldsymbol{R}$. sanguineus realiza quatro gerações anuais em Goiânia. Por outro lado, se os tratamentos não interferiram no desenvolvimento dos picos de atividade, mais de quatro picos de cada estágio ocorreram nos cães. Então, é aceitável supor que mais de uma população de $\boldsymbol{R}$. sanguineus estava se desenvolvendo no canil, ao mesmo tempo. O número médio de carrapatos de cada estádio foi similar nas estações do ano. Os sítios preferenciais de fixação foram o pescoço, o peito, as patas, as axilas, as orelhas, os espaços interdigitais e a cabeça. O número de carrapatos contados nos cães da raça Cocker Spainel Inglês foi de 1,4 a 11,5 vezes maior que o número observado nos cães sem raça definida.

Palavras-chave: Rhipicephalus sanguineus, carrapato vermelho dos cães, cães sem raça definida, Cocker Spaniel Inglês, dinâmica sazonal.

IEscola de Veterinária, Universidade Federal de Goiás (UFG), Goiânia, GO, Brasil.

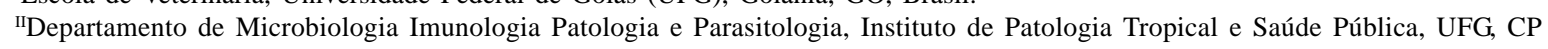
131, 74001-970, Goiânia, GO, Brasil. E-mail: lígia@iptsp.ufg.br. Autor para correspondência. 


\section{INTRODUCTION}

The cosmopolitan brown dog tick Rhipicephalus sanguineus (Latrielle 1806) is one of the most important ectoparasites affecting dogs. In some areas of the world $\boldsymbol{R}$. sanguineus has been reported feeding on a wide variety of medium and largesized mammals and ground-feeding birds (USDA, 1976). In Brazil, however, this tick species is most often found in dogs (LABRUNA \& PEREIRA, 2001a).

R. sanguineus causes discomfort, anemia and is known as the main vector of Ehrlichia canis, Babesia canis, Haemobartonella canis (WOLDEHIWET \& RISTIC, 1993), and Hepatozoon canis (O’ DWYER \& MASSARD, 2001). In Europe, $\boldsymbol{R}$. sanguineus can transmit to humans the agent of the Boutonneuse Fever, Rickettsia conorii (MERLE et al., 1998). DEMMA et al. (2005) determined that $\boldsymbol{R}$. sanguineus is a vector of Rickettsia rickettsii in Arizona, USA and, in Brazil, it is also regarded as a potential vector of this agent (ROZENTAL et al., 2002).

R. sanguineus is a three-host tick, with endophilous nidicole behavior (SONENSHINE, 1993), known as the "kennel-tick". Studies on its seasonal dynamics have been carried out in many parts of the world, such as Italy (STELLA et al., 1988; PRINCIPIATO et al., 1989), Spain (ESTRADA-PEÑA et al., 1992), India (DAS \& BHATIA, 1994), Japan (INOKUMA, 1996), Mexico (CRUZ-VAZQUEZ \& GARCIA-VAZQUEZ, 1999), and South Africa (JACOBS et al., 2001). Although $\boldsymbol{R}$. sanguineus is highly prevalent on dogs in Brazil (LABRUNA \& PEREIRA, 2001a; 2001b; RODRIGUES et al., 2001), no studies have been carried out on its seasonality in dogs or in the environment. The present study was aimed at determining the seasonal dynamics of larval, nymphal and adult $\boldsymbol{R}$. sanguineus infestations on seven naturally infested dogs from a Police unit in Goiânia, Goiás, Brazil.

\section{MATERIALS AND METHODS}

The experiment was carried out at a kennel of a Police unit in Goiânia (16² 40’S, 49 15’ W, altitude $741 \mathrm{~m})$, State of Goiás, Brazil, from July 2001 to July 2002. This municipality has a distinct dry season from April to September (autumn and winter) and a wet season from October to March (spring and summer), with mean temperature, relative humidity and rainfall varying from $20.7^{\circ} \mathrm{C}$ to $24.6^{\circ} \mathrm{C}, 47 \%$ to $76 \%$ and $21.7 \mathrm{~mm}^{3}$ to $222.5 \mathrm{~mm}^{3}$, respectively.

The kennel had an area of $1250 \mathrm{~m}^{2}$ with 30 stalls for two dogs each, divided into three pavilions. The experimental dogs were maintained in a separated pavilion $\left(115 \mathrm{~m}^{2}\right)$, at least six meters apart from other pavilions, with 8 stalls of $2.5 \times 5 \mathrm{~m}$, and strictly isolated from contact with other dogs. All dogs in the kennel were naturally infested with $\boldsymbol{R}$. sanguineus; however, due to the nidicole behavior of this tick (SONENSHINE, 1993), exchange of tick stages between the pavilions was not expected to occur. Besides, several measures were adopted in order to avoid any potential exchanges of ticks, such as: the experimental dogs had no contact with other dogs of the kennel; wax was scattered over the walls to prevent movement of ticks; weekly, 0.025\% of amitraz (Bovitraz, Bayer) was sprayed on the outside walls; the personnel taking care of the experimental animals had no contact with other dogs; and each experimental place had its exclusive cleaning material.

The study was carried out on seven dogs (two English Cocker Spaniels and five mongrel dogs), with ages ranging from six months to 10 years, naturally infested with $\boldsymbol{R}$. sanguineus. One month previous to the beginning of the experiment, the dogs were lodged in the kennel stalls and were allowed to be infested with resident $\boldsymbol{R}$. sanguineus. All dogs had been vaccinated with Octa-Cino-Vacin (Biovet), against rabies, and had been treated with anthelmintic (Drontal, Bayer). The animals were fed twice a day, received water "ad libitum" and were examined by a veterinarian twice a week. When the level of infestation reached above 500 adult ticks per animal (it ranged from 594 to 1108), the dogs were treated with 2 liters of $0.05 \%$ of coumaphos (Asuntol, Bayer), using a hand sprayer. This level of infestation was adopted based on previous results, in which a significant decrease in the packed cell volume was observed when infestation reached 500 ticks (unpublished data). Three animals became sick and were replaced during the experiment: one English Cocker Spaniel in December 2001 and two mongrel dogs in March 2002. Clinical and laboratorial examinations diagnosed canine distemper in two of them and ehrlichiosis in the third dog. Those three dogs were replaced by three tick-free mongrel dogs, which were monitored one month later of their placement in the stalls.

Every two weeks, the numbers of attached engorged larvae, nymphs and adults were recorded. The engorged immature stages were collected by brushing the left side of the animals, as previously described by OLIVEIRA et al. (2003) for collection of Amblyomma cajennense on horses. After consecutive brushings, the larvae and nymphs were collected and placed into plastic bags and then transported to the laboratory for counting and species identification. The numbers of adult stages were estimated by counting parasites on the attachment sites on the left side of the 
animals: (1) head, (2) ears (3) between toes, (4) neck, armpits, forelegs and chest, (5) back, abdomen, hind legs, groin, and tail. The number of ticks counted on the left side was doubled to provide an estimate of the total number of ticks per animal.

Identification of ticks was carried out on adult specimens collected in all countings, according to ARAGÃO \& FONSECA (1961). A sample corresponding to thirty percent of the larvae and the nymphs were also examined; larvae were identified using the CLIFFORD \& ANASTOS (1960) key, and nymphs were identified using the same characteristics described by ARAGÃO \& FONSECA(1961) for adults.

Climatic variables, including mean temperature, rainfall and relative humidity, were obtained from the weather station of the Goiânia Meteorological District (Figure 1).

The results were submitted to a variance analysis and the means were compared using the Student's t-test. The data were log transformed $(\mathrm{x}+1)$ before the analysis (SAMPAIO, 1998). The effect of the season on the dynamic of the tick was evaluated by comparing the dry seasons (autumn and winter) with the wet seasons (spring and summer).

\section{RESULTS AND DISCUSSION}

Ticks were found feeding on dogs throughout the year and all of them were identified as R. sanguineus. When comparing data from the cold dry seasons (autumn and winter) with those from the hot wet seasons (spring and summer), the mean numbers of ticks were statistically $(\mathrm{P}>0.05)$ similar, ranging from 176.6 to 223.0 for adults, 23.6 to 16.4 for larvae, and 31.3 to 46.6 for nymphs. These results are not in agreement with the literature. GILOT (1984), in France, reported higher numbers of adults during the summer and higher numbers of immature stages (both larvae and nymphs) during the spring. In Italy, STELLA et al. (1988); PRINCIPIATO et al. (1989) found all stages of R. sanguineus in the spring and summer. DAS \& BHATIA(1994), in India, observed a single yearly peak of ticks from March to September. CRUZ-VAZQUEZ and GARCIA-VAZQUEZ (1999), in Mexico, reported higher prevalence rates of ticks during spring, summer and fall than during the winter. In Minas Gerais State, Brazil, infestations of $\boldsymbol{R}$. sanguineus have higher intensity during the hot and rainy months (RODRIGUES et al. 2001). In South Africa, JACOBS et al. (2001) observed dogs infested with $\boldsymbol{R}$. sanguineus throughout the year, with the highest number of ticks being collected during the warmer months (January to April).
The constant high prevalence rates of $\boldsymbol{R}$. sanguineus stages throughout the year observed in the present study is probably due to the optimal conditions for their development at the experimental site, which may explain the data differences among the studies. As observed in most tick species, the hostseeking stages of $\boldsymbol{R}$. sanguineus are under the influence of climatic conditions, such as temperature and relative humidity (HEATH, 1981; BELLATO \& DAEMON, 1997). On the other hand, the development of feeding stage depends exclusively on the availability of the specific host (SARTOR et al., 1996). According to the weather station, during the experiment, the mean temperature in Goiânia ranged from 23.5 to $26.5^{\circ} \mathrm{C}$, the relative humidity from 45 to $80 \%$ and the rainfall from 0 to $400 \mathrm{~mm}$ (Figure 1). Due to the fact that the stalls were washed twice a day, it is probable that the relative humidity in the stalls was different from that measured at the weather station. Thus, in despite of the relative humidity levels measured in the station being bellow the ideal indices for $\boldsymbol{R}$. sanguineus, as pointed out by JACOBS et al. (2001), the relative humidity within the stalls was probably higher. The mild temperatures, the increased relative humidity and the constant presence of dogs provided ideal conditions to the development of $\boldsymbol{R}$. sanguineus ticks.

The acaricide treatments were applied on September 10, and on December 3, in two dogs, and on February 15, in one dog. There was a decrease in the numbers of larvae (87\%) and adults (90\%) in the first count after the two acaricide treatments. However, in the second count, no increase was observed in the number of both stages: adults (62\%) and larvae (70\%) (Figures 2a and 2b). The sharp decrease immediately after the treatment indicates that the acaricide interfered with the development of larval and adult peaks, raising the hypothesis that if no acaricide had been used, the number of larvae and adults would not have decreased abruptly during that period. On the other hand, the number of nymphs did not increase in the second count after either treatment. Since the acaricide treatments were based on a short residual period, it is reasonable to assume that this reduction in the number of nymphs would have occurred even if no acaricide had been used. On this perspective, it is possible to infer that the third acaricide treatment did not interfere with the peaks of any tick stages, since the number of ticks was low for at least two counts. Under this point of view, the results indicate the occurrence of the following peaks: - larvae (four peaks): August to November, November to February, March to May, May to July (Figure 2a); nymphs (five peaks): July to September, October to December, December to February, March to 


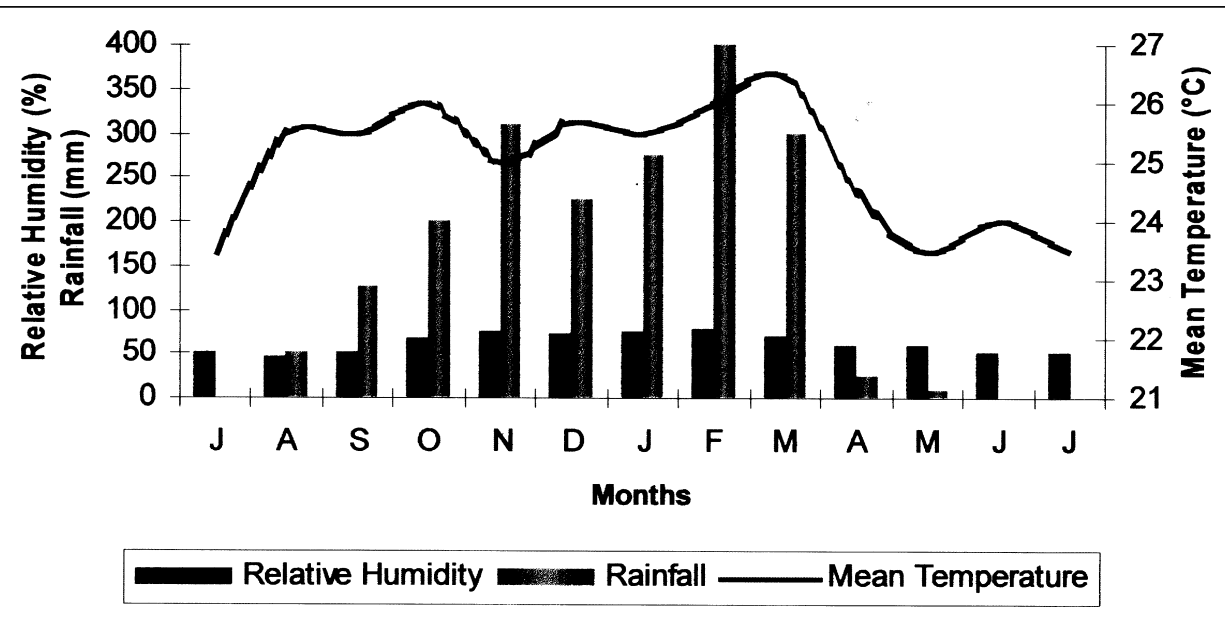

Figure 1 - Climatic data from the Goiânia Meteorological District, Goiás, Brazil, from July 2001 to July 2002.

May, June to July (Figure 2b); and adults (four peaks): July to October, October to January, January to March and April to July (Figure 2c). The dynamic of larvae, nymphs and adults on untreated dogs was very similar to those aforementioned. However, as the peaks were flatter than those including both treated and untreated animals, the complete data were maintained.

The occurrence of four to five consecutive peaks of activity of each stage of $\boldsymbol{R}$. sanguineus indicates that this tick can develop up to four generations yearly in Goiânia, where dogs are constantly available. In fact, as the experiment lasted 13 months, we can conclude that a fifth peak of feeding nymphs seemed to occur at the beginning of the first peak of activity, because they occurred concomitantly. Considering that $\boldsymbol{R}$. sanguineus may develop four generations yearly in Goiânia, the duration of the complete cycle would be 91 days. These data are in agreement with those obtained by BECHARA et al. (1995), in which $\boldsymbol{R}$. sanguineus stages fed on dogs and maintained at a temperature of $27^{\circ} \mathrm{C}$ developed a complete cycle within 90 days.

The mean temperature observed in Goiânia during the experiment (Figure 1) would not justify the occurrence of a complete cycle shorter than that observed by BECHARA et al. (1995) at $27^{\circ} \mathrm{C}$. Thus, if the assumption about the interference of acaricide treatment with the development of larval and adult peaks is not correct, more than four peaks of each stage would occur on the dogs. Therefore, it is reasonable to assume that more than one population of $\boldsymbol{R}$. sanguineus was developing in the kennel during the experimental period. The activity peaks would thus represent an overlapping of different populations occurring during the year, rather than four generations of one population.
Higher numbers of adults $(14,446)$ than nymphs $(2,445)$ or larvae $(1,299)$ were observed and this was due to the sampling technique. The brushing technique was not very efficient for collecting immature ticks, particularly the unengorged ones. On the other hand, nearly every adult ticks, engorged and unengorged, were collected because they were larger in size. The main feeding attachment sites for adults were the neck, chest, forelegs and armpits (29.5\%), the ears (24.6\%), spaces between toes (21.9\%), and the head (20.5\%). The preferences of $\boldsymbol{R}$. sanguineus for attachment on the neck, ears and between toes are in agreement with JACOBS et al. (2001) and RODRIGUES et al. (2001). However, we found higher numbers of ticks attached on the head than those reported by the previous mentioned authors.

During the entire experiment, although more evidently during the hot and wet months (from October to March), the number of adult ticks feeding on English Cocker Spaniel dogs was 1.4 to 11.5 fold higher than those feeding on mongrel dogs. An equivalent comparison could not be made for immature stages, since the brushing technique did not allow an efficient collection of these stages, particularly from longhair dogs such as the English Cocker Spaniels. The higher number of ticks observed on English Cocker Spaniel dogs could be explained on the basis of breed resistance or due to individual factors, as pointed out by SUTHERST et al. (1988) and RECHAV et al. (1991). However, with regard to this aspect, no conclusions were drawn, since the present study was not design to address this question. Considering that $\boldsymbol{R}$. sanguineus is a hunter tick (SONENSHINE, 1993), it is possible that the host produces some key factors to activate or 


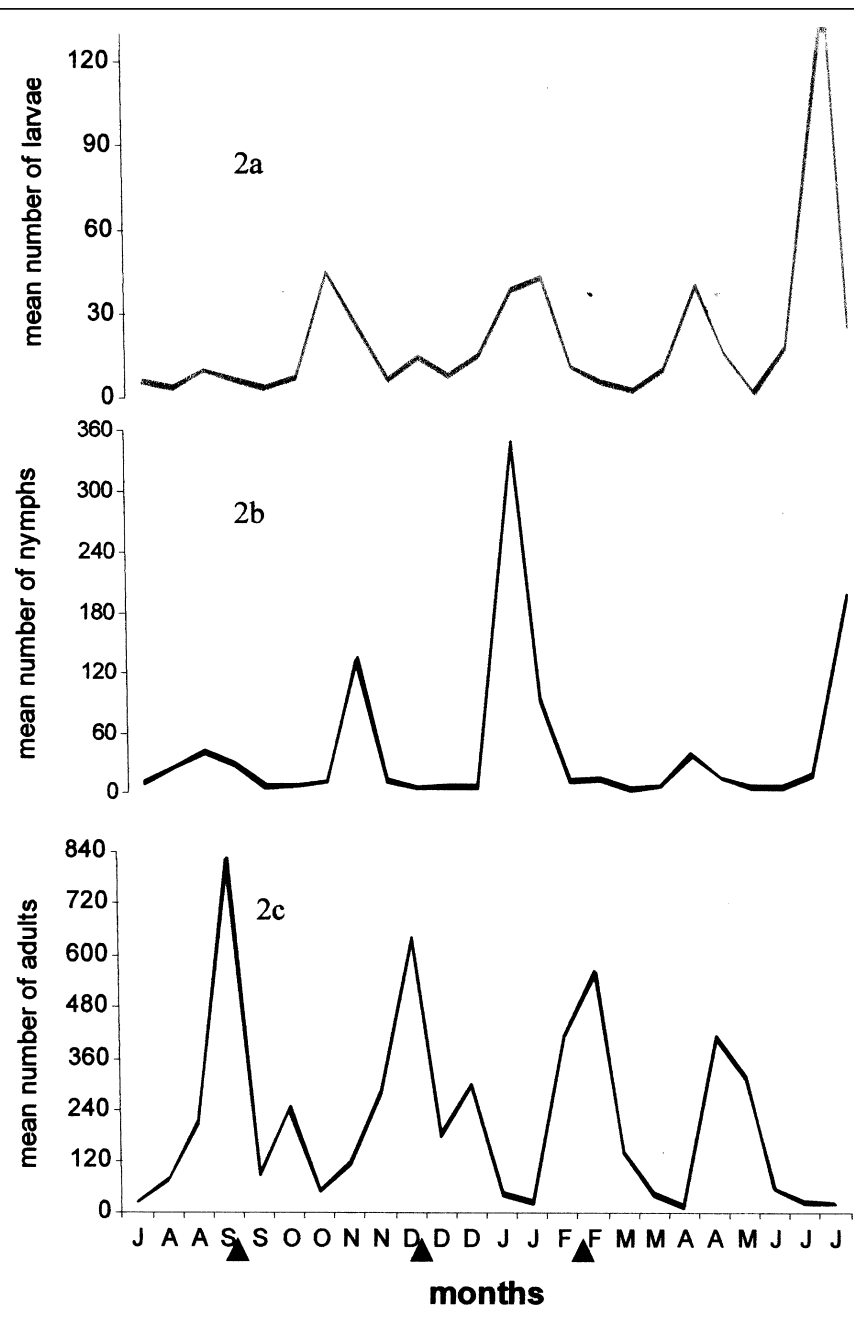

Figure 2 - Mean number of $\boldsymbol{R}$. sanguineus larvae (a), nymphs (b) and adults (c) feeding on dogs in a kennel of a Police unit in Goiânia, Goiás, Brazil, from July 2001 to July 2002. The arrows indicate the acaricide treatments.

\section{REFERENCES}

ARAGÃO, H.; FONSECA, F. Notas de ixodologia. VIII. Lista e chave para os representantes da fauna ixodológica brasileira. Memórias do Instituto Oswaldo Cruz, Rio de Janeiro, v.59, n.2, p.115128, 1961.

BECHARA, G.H. et al. Rhipicephalus sanguineus in Brazil: feeding and reproductive aspects under laboratorial conditions. Revista Brasileira de Medicina Veterinária, Rio de Janeiro, v.4, n.2, p.61-66, 1995.

BELlATO, V.; DAEMON, E. Efeitos de três temperaturas sobre a fase não parasitária de Rhipicephalus sanguineus (Latreille, 1806) (Acari: Ixodidae). Revista Brasileira de Parasitologia Veterinária, São Paulo, v.6, n.1, p.21-27, 1997.

CLIFFORD, C.M.; ANASTOS, G. The use of chaetotaxy in the identification of larval ticks (Acarina: Ixodidae). Journal of Parasitology, Lawrence, v.46, p.567-578, 1960.

CRUZ-VAZQUEZ, C.; GARCIA-VAZQUEZ, Z. Seasonal distribution of Rhipicephalus sanguineus ticks on dogs in urban area of Morelos, Mexico. Experimental and Applied Acarology, Amsterdam, v.23, n.3, p.277-280. 1999.

DAS, S.S.; BHATIA, B.B. Seasonal activity of ixodid ticks in herbage in Pantnagar. Indian Journal of Veterinary Research, Índia, v.3, n.2, p.42-46, 1994.

DEMMA, L.J. et al. Rocky mountain spotted fever from an unexpected tick vector in Arizona. New England Journal of Medicine, Massachusetts, v.353, n.6, p.587-594, 2005.

ESTRADA-PEÑA, A. et al. An account of the ticks of the northeastern of Spain. Annales de Parasitologie Humaine et Comparée, Paris, v.67, n.2, p.42-49, 1992.

inhibit the host-seeking behavior of this tick, but further investigations are necessary to confirm the occurrence of $\boldsymbol{R}$. sanguineus-resistant breeds of dogs and the causes of this resistance.

\section{CONCLUSION}

R. sanguineus may develop up to four generations yearly in Goiânia - GO, Brazil, unless more than one population of $\boldsymbol{R}$. sanguineus was developing in the kennel at the same time.

\section{ACKNOWLEDGEMENTS}

The authors are grateful to Bayer-Brasil for the financial support for the project, and to the personnel at the Police Kennel of Goiânia-GO, who offered the facilities for the development of the experiment.
GILOT, B. Biologie et ecologie de Rhipicephalus sanguineus (Latrielle, 1806) (Acarient: Ixodoidea) dans le Sud-est de la France. Sciences Vétérinaires Medicine Comparée, Charbonnieres Cedex, v.86, n.1/2, p.25-33, 1984.

HEATH, A.C.G. The temperature and humidity preferences of Haemaphysalis longicornis, Ixodes holocyclus and Rhipicephalus sanguineus (Ixodidae): studies on engorged larvae. International Journal of Parasitology, Oxford, v.11, n.2, p.169-175, 1981.

INOKUMA, H. et al. Seasonal distribution of Rhipicephalus sanguineus in Okayama Prefecture, Japan and effect of temperature on development of tick. Journal of Veterinary and Medical Science, Tokyo, v.58, n.3, p.225-228. 1996.

JACOBS, P.A.H. et al. Diversity, seasonality and sites of attachment of adults ticks on dogs in the central region of the Free State Province, South Africa. Onderstepoort Journal of Veterinary Research, Pretoria, v.68, n.4, p.281-290, 2001. 
LABRUNA, M.B.; PEREIRA, M.C. Carrapato em cães no Brasil. Clínica Veterinária, São Paulo, v.6, n.30, p.24-32, 2001a.

LABRUNA, M.B.; PEREIRA, M.C. Febre maculosa: aspectos clínico-epidemiológicos. Clínica Veterinária, São Paulo, v.3, n.12, p.19-23. 2001 b.

MERLE, C. et al. Disease course of Mediterranean Spotted Fever: remark on 16 cases. 7e Colloque sur le Controle Epidemiologique des Maladies Infectieuses, Paris, France. Medecine et Maladies Infectieuses, Paris, v.28, n.5, p.400401, 1998.

O’DWYER, L.H.; MASSARD, C.L. Aspectos gerais da hepatozoonose canina. Clínica Veterinária, São Paulo, v.6, n.31, p.34-40, 2001.

OLIVEIRA, P.R. et al. Seasonal dynamics of the Cayenne tick, Amblyomma cajennense on horses in Brazil. Medical and Veterinary Entomology, Oxford, v.17, n.4, p.412-416, 2003.

PRINCIPIATO, M. et al. Preliminary study of seasonal distribution of some Ixodidae of medical importance in the province of Perugia, Central Italy. Bulletin de la Societé Francaise de Parasitologie, Paris, v.7, n.2, p.269-276, 1989.

RECHAV, Y. et al. Resistance of indigenous African cattle to the tick Amblyomma hebraeum. Experimental and Applied Acarology, Amsterdam, v.12, n.3/4, p.229-241, 1991.

RODRIGUES, A.F.S.F. et al. Investigação sobre alguns ectoparasitos em cães de rua no município de Juiz de Fora, Minas Gerais. Revista Brasileira de Parasitologia, Veterinária, São Paulo, v.10, n.1, p.13-19, 2001.
ROZENTAL, T. et al. Evidence of spotted fever group rickettsiae in State of Rio de Janeiro, Brazil. Revista do Instituto de Medicina Tropical de São Paulo, São Paulo, v.44, n.3, p.155-158, 2002

SAMPAIO, I.V.B. Estatística aplicada à experimentação animal. Belo Horizonte: UFMG/FEPMVZ, 1998. 221p.

SARTOR, A.A. et al. Aspects of the biology of Rhipicephalus sanguineus (Latrielle, 1806) (Acari:Ixodidae) under laboratory conditions: feeding phase of larvae and nymphs. Revista Brasileira de Medicina Veterinária, Rio de Janeiro, v.18, n.1, p.14-17, 1996.

SONENSHINE, D.E. Biology of ticks. Oxford: Oxford University, 1993. 463p.

STELLA, E. et al. New data on the biology of Rhipicephalus sanguineus in the outskirts of Rome. Rivista di Parasitologia, Italy, v.49, n.1, p.3-12, 1988.

SUTHERST, R.W. et al. Ecology of the cattle tick (Boophilus microplus) in subtropical Australian. II. Resistance of different breeds of cattle. Australian Journal of Agricultural Research, Victoria, v.39, n.2, p.299-308, 1988

UNITED STATES DEPARTMENT OF AGRICULTURE. Ticks of Veterinary Importance. Washington, 1976. 122p. (Agriculture Handbook, 485).

WOLDEHIWET, Z.; RISTIC, M. Rickettsial and Chlamydial diseases of domestic animals. Oxford: Pergamon, 1993. 427p 